\title{
THE REALISATION OF THE CONSTITUTIONAL PRINCIPLES - THE RIGHT TO GOOD ADMINISTRATION AND THE RIGHT TO LEGAL REMEDY - IN HUNGARY
}

\author{
Nora Balogh-Bekesi, Kitti Pollak \\ National University of Public Service, Budapest, Hungary
}

\begin{abstract}
The paper aims to present the realisation of two procedural principles - the right to good administration and the right to legal remedy - regulated also in the Fundamental Law of Hungary, which entered into force on $1^{\text {st }}$ January 2012. The right to legal remedy has been a constitutional principle since the change of regime (in 1989) and the right to good administration has been constitutionally named only by the Fundamental Law of Hungary. The actuality of the paper is the fact that in Hungary from the $1^{\text {st }}$ of January 2018 completely new codes regulate the general public administrative procedures and the administrative justice. Based on these Acts, a new legal remedy system has been introduced regarding administrative decisions in which the judicial review procedures became instead of the internal administrative appeal procedures - in most of the cases the firstly used legal remedy possibility regarding administrative decisions. After a short overview of the new legal remedy system which has been introduced regarding administrative decisions, the paper presents the constitutional basis of the right to good administration and the right to legal remedy. Finally, we analyse in detail the latest and most relevant decisions of the Constitutional Court of Hungary and some cases of the Curia of Hungary about the practice of the direct enforcement of the constitutional principles: the right to good administration and the right to legal remedy regarding administrative decisions.
\end{abstract}

Key words: the right to legal remedy, the right to good administration, Hungary, principle of procedural fairness, reasonable time, duty to justify decisions, obligation for cooperation between the administrative bodies and the clients.

\section{INTRODUCTION}

The right to good administration and the right to legal remedy, are constitutional principles, fundamental rights, more precisely procedural rights. ${ }^{1}$ Examining the application of these rights in administrative authority's decision-making process is one of the most interesting and current questions in Hungary. This analysis is even more actual, because from $1^{\text {st }}$ January 2018 the new Code of Administrative Procedures called Act CL. of 2016 on General Public Administration Procedures entered into force. It includes all general regulations regarding administrative procedures. ${ }^{2}$ At the

1 See: VICE ÁDÁNY, T., BALOGH-BÉKESI, N., BALOGH, Z., HAJAS, B. Rights and Freedoms. In VARGA, A. Zs., PATYI, A., SCHANDA, B. The Basic (Fundamental) Law of Hungary, A commentary of the New Hungarian Constitution. Dublin : Clarus Press, NUPS, 2015, pp. $79-123$.

2 Administrative procedures can be determined as the proceedings of the administrative authorities, including the issues of the administrative actions in accordance with the legislation. See: PATYI, A. et al. Közigazgatási hatósági eljárásjog. Budapest-Pécs : Dialóg Campus Kiadó, 2009, pp. 19 - 30. 
same time, one of the last years most important codification has been realised in Hungary: Act I. of 2017 on Administrative Justice entered into force on $1^{\text {st }}$ January 2018 and contains rules of the judicial review procedures of the administrative decisions. ${ }^{3}$

Before the detailed examination of this complex topic, the paper includes a general overview of the constitutional basis of the right to legal remedy and the right to good administration. Furthermore, the paper examines the relation between the right to legal remedy and the right to good administration. In the last part of the paper, we analyse few relevant cases regarding the realisation of several rights and obligations like the requirement of a decision within a reasonable time, the duty to justify decisions and the obligation for the cooperation between the administrative bodies and the clients. ${ }^{4},{ }^{5}$ These rights and obligations are also part of the right to good administration. We need to note that the right to good administration can be better understood by the rights derived from it, but unfortunately - considering the limitation on the length of the paper - we can only highlight the latest and the most relevant cases regarding the realisation of the right to good administration and can not cover all aspects of this principle. ${ }^{6}$ The presented cases in the paper are decisions of the Constitutional Court of Hungary and the Curia of Hungary. We have to emphasize that the Constitutional Court of Hungary among other competances - has the right to (at the initiative of a judge) review the conformity with the Fundamental Law of any legal regulation applicable in a particular case with priority but within ninety days at the latest. The Constitutional Court of Hungary has also the possibility to review - on the basis of a constitutional complaint - the conformity with the Fundamental Law of any legal regulation applied in a particular case. The Constitutional Court of Hungary reviewes - on the basis of a constitutional complaint - the conformity with the Fundamental Law of any judicial decision too. In the first two cases, the Constitutional Court of Hungary can annul any legal regulation or any provision of a legal regulation which conflicts with the Fundamental Law. In the last case, the Constitutional Court of Hungary has the right to annul any judicial decision which conflicts with the Fundamental Law. ${ }^{7}$ We should also mention that the Curia of Hungary is the supreme judicial organ and can review final decisions of the lower courts (also the decisions made by the Administrative and Labour Courts) if these are challenged through an extraordinary remedy. ${ }^{8}$ Without a detailed examination of the Hun-

3 The Code of Administrative Justice was first accepted on $6^{\text {th }}$ December 2016, and abolished by the Constitutional Court by the Decision 1/2017. (I. 17.) because one part of the Act was unconstitutionally accepted by Parliament. See: POLLÁK, K. Quo Vadis: Codification of Administrative Procedure Rules in Hungary and in France In NEMEC, J (ed.). $25^{\text {th }}$ NISPAcee Annual Conference: Innovation Governance in the Public Sector, Kazan, Oroszország, 2017. 05. 18 - 2017. 05. 20. Bratislava : NISPAcee, 2017, pp. $1-8$.

4 Article 10 of the Act CL. of 2016 on General Public Administration Procedures defines the notion client as follows: "(1) Client means any natural or legal person, other entity whose rights or legitimate interests are directly affected by a case, who is the subject of any data contained in official records and registers, or who is subjected to regulatory inspection.

(2) An act or government decree may define the persons and entities who can be treated as clients - in connection with certain specific types of cases - by operation of law."

5 That part of the paper is based on a thesis regarding procedural fairness prepared by BALOGH-BEKESI Nora in a coproject of the Constitutional Court of Hungary and the Curia of Hungary.

6 See: SULYOK, T. A tisztességes eljáráshoz való jog újabb kihívásai. In Alkotmánybírósági Szemle, 2. szám (2015).

7 See the competences of the Constitutional Court of Hungary: Article 24 of the Fundamental Law of Hungary, BALOGH, Z. Alkotmánybíróság. In TRÓCSÁNYI L., SCHANDA B. (eds.). Bevezetés az alkotmányjogba. Az Alaptörvény és Magyarország alkotmányos intézményei. Budapest : HVG-ORAC, 2016, 406 - 423, Téglási, A. Az Alkotmánybíróság. In TÉGLÁSI, A (eds). Az állam szervezete. Budapest : NKE, 2018, p. 160 - 180.

8 PATYI, A. The Courts and the Judiciary In VARGA, A. Zs., PATYI, A., SCHANDA, B. The Basic (Fundamental) Law of Hungary, A commentary of the New Hungarian Constitution. Dublin :Clarus Press, NUPS, 2015, p. 204 - 213, BALOGHBÉKESI, N. A bírói hatalmi ág az Alaptörvény rendszerében. In IUSTUM AEQUUM SALUTARE, XII., 4 (2016), pp. 9 19. Available at <http://ias.jak.ppke.hu/hir/ias/20164sz/02_BaloghBekesi_IAS_2016_4.pdf >. [q. 2018-05-29]. 
garian judicial system, we would like to point out that from $1^{\text {st }}$ of January 2013, twenty Administrative and Labour Courts located in the seat of regional courts started to function. The Administrative and Labour Courts proceed in first instance in cases reviewing administrative decisions, however we can not regard these Courts as an independent administrative judicial branch. ${ }^{9}$ We shall state also that according to Article 28 of the Fundamental Law of Hungary: "In the course of the application of law, courts shall interpret the text of legal regulations primarily in accordance with their purposes and with the Fundamental Law. When interpreting the Fundamental Law or legal regulations, it shall be presumed that they serve moral and economical purposes which are in accordance with common sense and the public good."

\section{CONSTITUTIONAL BASIS OF THE RIGHT TO GOOD ADMINISTRATION AND THE RIGHT TO LEGAL REMEDY}

Due to the changes in 1989, the Hungarian Constitution which was at that time Act XX. of 1949 was almost completely modified. The right to legal remedy was amended and became part of the Constitution at that time with the following wording: "In the Republic of Hungary everyone may seek legal remedy, in accordance with the provisions of the laws, to judicial, state administrative or other official decisions, which infringe on his rights or justified interests." ${ }^{10}$ Meanwhile, the principle of procedural fairness expressis verbis was not mentioned in 1989 in the Constitution of Hungary. This principle word-for-word became only the part of the Hungarian legal system and was mentioned by the Act XXXI. of 1993, which incorporated into the Hungarian legal system the European Convention on Human Rights. Article 6 of the European Convention on Human Rights declares the right to fair trial as follows: "In the determination of his civil rights and obligations or of any criminal charge against him, everyone is entitled to a fair and public hearing within a reasonable time by an independent and impartial tribunal established by law." ${ }^{11}$

In 2011, a new Constitution of Hungary, named the Fundamental Law of Hungary was adapted, which came into force on the $1^{\text {st }}$ January 2012. The Fundamental Law mentions the principle of procedural fairness in two aspects: one is regarding administrative procedures. The principle of procedural fairness is regulated as the right to good administration in paragraph 1 of Article XXIV. of the Fundamental Law of Hungary as follows: "Everyone shall have the right to have his or her affairs handled impartially, fairly and within a reasonable time by the authorities. Authorities shall be obliged to give reasons for their decisions, as provided for by an Act." The other one is regarding court proceedings, where the principle of procedural fairness is named as the right to a fair trial and regulated in paragraph 1 of XXVIII. of the Fundamental Law of Hungary as follows: "Everyone shall have the right to have any charge against him or her, or his or her rights and obligations in

9 KÜPPER H. Magyarország átalakuló közigazgatási bíráskodása. MTA Law Working Papers 2014/59. Budapest : Magyar Tudományos Akadémia, 2014, pp. 19 - 29.

10 POLLÁK, K. Historical roots of articicle XXVIII, section 7 of the fundamental law of Hungary: On the right to seek legal remedy. In BALOGH, E., SULYOK, M. (eds.). Fundamental rights in Austria and Hungary: Research seminar Vienna, 24 - 25. april 2015. Szeged : Iurisperitus Bt., 2015, pp. 29 - 32.

11 See also: BOROS, A. Az alapelvek szerepe az uniós és tagállami közigazgatási eljárásjogok rendszerében - A Modell Szabályok értékelése és javaslatok megfogalmazása az uniós alapelvek eljárásjogi szabályozását illetően. In Pro Publico Bono, $/ 2$ (2017), pp. $30-47$. 
any litigation, adjudicated within a reasonable time in a fair and public trial by an independent and impartial court established by an Act."

We can point out from the quoted paragraphs of the Fundamental Law of Hungary that the Fundamental Law of Hungary mentions the requirement of a decision within a reasonable time and several other requirements as the part of the principle of procedural fairness. ${ }^{12}$ The two aspects of the principle of procedural fairness can be understood in connection with each other too; for example, the duty to justify decisions can be found in administrative procedures as well as in judicial proceedings. We should also emphasize that the right to good administration includes several requirements and rights like the right to legal remedy, the requirement of a decision within a reasonable time, the duty to justify decisions and other procedural rights such as the obligation for the cooperation between the administrative bodies and the clients, which we will discuss in the following parts of this paper.

\section{THE RELATION BETWEEN THE RIGHT TO LEGAL REMEDY AND THE RIGHT TO GOOD ADMINISTRATION}

The right to a legal remedy can be considered as the strongest right between the rights and obligations of the principle of procedural fairness. The practice of the Constitutional Court of Hungary clarifies the exercise of the right to legal remedy: the substantive content of the right to legal remedy is the possibility regarding final decisions to turn to a different body or a higher forum within the same organization. ${ }^{13}$ This requirement can be accomplished by a single appeal system, but the legislator may also provide further remedies. ${ }^{14}$ The essence of all remedies is the possibility to have an effective remedy: to correct infringements. ${ }^{15}$ We should note that administrative procedures would not comply with the Fundamental Law of Hungary without providing the opportunity for legal remedy. ${ }^{16}$

The basis of the relation between the right to good administration and the right to legal remedy was laid down in the Decision 39/1997 (VII.1.) of the Constitutional Court of Hungary. ${ }^{17}$ This Decision dealt with questions related to the Hungarian Medical Association and its membership's provisions. The Hungarian Medical Association is one of the Professional Chambers in Hungary, which are found to be the governing bodies of the traditional professions, composed of their members, so

12 CHRONOWSKI, N. Mikor megfelelő az ügyintézés? Uniós és magyar alapjogvédelmi megfontolások. In Magyar Jog, 3 (2014), pp. $137-145$.

13 Decision 5/1992. (I. 30.) of the Constitutional Court of Hungary See in relation with administrative prodecures: BOROS, A., PATYI, A. Administrative Appeals and Other Forms of ADR in Hungary. In DRAGOS, D. C., NEAMTU, B. (eds.). Alternative Dispute Resolution in European Administrative Law. Berlin, Heidelberg : Springer-Verlag, 2014, pp. 279 339.

14 Decision 9/1992. (I. 30.) of the Constitutional Court of Hungary.

15 Decision 49/1998. (XI. 27.) of the Constitutional Court of Hungary.

16 See: POLLÁK, K. Achievement of the right to legal remedy in the Hungarian Administratives Procedures. In CICKANOVA, D., ILLYOVA, Z., MICATEK, V., RUZICKA O. (eds.). Collection of Papers from the International Academic Conference Bratislava Legal Forum 2013. Bratislava : Comenius University in Bratislava, Faculty of Law, 2014, pp. $121-131$

17 See: Official Translations/Summaries of the Decisions of the Constitutional Court of Hungary. Available at <http:// www.codices.coe.int/NXT/gateway.dll/CODICES/precis/eng/eur/hun/hun-1997-2-008?fn=document-frameset. htm $\$ \mathrm{f}=$ templates $\$ 3.0>$. [q. 2018-05-29]. 
as to exercise a form of self-government. In the current case, the Hungarian Medical Association decided on the non-Hungarian citizens medical practitioner's membership, but the problem was that there was no legal provision regulating the circumstances under which the Hungarian Medical Association should accept or refuse the request of the foreign medical practitioner. Therefore, the right to appeal to the courts in case of a refusal does not make any sense in this situation, since the Court cannot examine the legality of such a decision. Consequently, the Constitutional Court of Hungary held the challenged provision unconstitutional. In this decision, the Constitutional Court of Hungary also expressed that in a case concerning the supervision of the legality of a public administrative authority's decisions, it is a constitutional requirement that the Court shall decide the case according to the rights and obligations set forth in Article 57 of the Constitution, under which all persons are equal before the law and have the right to defend themselves against any charge brought against them, or, in a civil suit, to have their rights and duties judged by an independent and impartial court of law at a fair public trial or hearing. The rule regulating a public administrative authority's right to decide cases must contain provisions under which the Court has supervisional jurisdiction over the legality of this kind of decision. In summary, all legislation that excludes or restricts the Court's review of the administrative decision is contradictory to the requirement of fair trial and to the right to a legal remedy. Consequently, any Act is unconstitutional, which gives an unlimited discretion to the administrative authorities without any legal background.

In connection with the practice regarding the realisation of the right to legal remedy another interesting case $^{18}$ should be notified from the latest Decisions of the Constitutional Court of Hungary. The background of this case is the following: the administrative authority made a decision in which it mentioned that the right to legal remedy against this administrative decision can be exercised within thirty days. The problem was that the law stated not thirty days, but only fifteen days as a period within which it is possible to bring an action against this kind of administrative decision. The Administrative and labour court - which proceeded in the first instance in this case of reviewing the administrative decision - dismissed and rejected without examination the applicant's request for judicial review of the administrative decision, on the ground that the request for judicial review was brought out of time. After the decision made by the Administrative and labour court, a constitutional complaint was lodged. The Constitutional Court of Hungary found unconstitutional and annulled the decision of the Administrative and labour court on the basis that the constitutional right, the right to good administration, more precisely the right to legal remedy, was infringed because of the fact that an incorrect information was given by the administrative authority in its own decision regarding the time frame of the exercise of the right to legal remedy. As a result, the applicant did not have an adequate and effective remedy, therefore it can be considered as an infringement of his fundamental right which had a decisive impact on the content of the Administrative and labour court's decision.

Finally, we should remark that in the practice of the Curia of Hungary the right to legal remedy and the right to good administration is related. One of the basis of the application of the right to good administration is the right to legal remedy. The Decision Kfv.IV.37.038/2016 of the Curia of Hungary stated that if the administrative authority does not make its decision in a correct form, and therefore it is impossible to exercise the right to legal remedy, the content of the decision should be taken into account, not its name or form how it was made. If the administrative authority finally

18 Decision 9/2017. (IV. 18.) of the Constitutional Court of Hungary. 
decides on the case in a form that there is no legal remedy possibility, this fact infringes the right to a legal remedy, the right to good administration. ${ }^{19}$

\section{ASPECTS OF THE RIGHT TO GOOD ADMINISTRATION}

As mentioned previously, the right to good administration contains several requirements and rights not only the right to legal remedy. Regarding the limitation on the length of the paper, only the requirement of a decision within a reasonable time, the duty to justify decisions and the obligation for cooperation between the administrative bodies and the clients are examined in the following part of the paper.

\subsection{The requirement of a decision within a reasonable time and the duty to justify decisions}

We can highlight from the practice of the Constitutional Court of Hungary, the Decision 5/2017. (III.10.) of the Constitutional Court of Hungary as the latest example of a case regarding the requirement of a decision within a reasonable time. The background of this case is the following: a thread company's wastewater exceeded the limit of the emissions of water pollutants. This was detected by the water channel service company, which proposed to the administrative authority on $18^{\text {th }}$ February 2014 to impose a penalty on the thread company. The administrative authority decided - one year later after this notification - on $17^{\text {th }}$ February 2015 that a penalty should be paid by the thread company. The thread company asked for a judicial review of this administrative authority's decision. The Administrative and Labour Court - which proceeded in the first instance in this case of reviewing the administrative decision - considered that the fact that administrative authority exceeded the administrative procedural time limit does not affect the substance of the case. The applicant presented a constitutional complaint against this decision of the Administrative and Labour Court. Contrary to the decision of the Administrative and Labour Court, the Constitutional Court of Hungary found that the Court decision is unconstitutional and annulled it. According to the Constitutional Court of Hungary, the basic condition for the fairness of an administrative procedure is that the administrative authority respects the time-limit of the decision-making period regulated in the law. The disrespect of the time-limit by an administrative authority can not cause a disadvantage for the applicant (in this case to the thread company). As we can see from the above mentioned case too, the requirement of a decision within a reasonable time is often linked to the question if it affects the substance of the case. The judicial practice shows that the violation of the time-limits by the administrative authority, if it causes a disadvantage for the client, affects the substance of the case.

We need to note, that the judicial practice also shows that the substance of the case is also affected if the decision was not justified well or was not at all justified by the administrative authority. The administrative authority's obligation to justify decisions is also the part of the right to good administration as declared in Paragraph 1 of Article XXIV of the Fundamental Law of Hungary. The latest practice of the Court of Hungary mentions regarding this question that the judgment of

19 See: Decision 1/2009 KJE of the Curia of Hungary. 
the administrative authority should be always coherent with the justification. The reasoning should contain all facts, proofs and of course the legal background. ${ }^{20}$

Finally, we should state that the enforcement of the principle of the requirement of a decision within a reasonable time seems to be even stricter in the latest practice of the Curia of Hungary. ${ }^{21}$ According to the previously mentioned Decision of the Constitutional Court of Hungary, the Curia of Hungary declared that the tax authority does not have the right to impose tax penalty after a deadline defined in the law. The background of this case is the following: the applicant received on the $17^{\text {th }}$ October 2014 a report of the tax inspection of the VAT returns carried out a posteriori by the Hungarian Tax Authority. After more than a half year later of this report's reception, the Hungarian Tax Authority decided on the report and in its decision the Hungarian Tax Authority ruled that the applicant should pay tax difference, tax penalty and late payment surcharge. After the $1^{\text {st }}$ instance Court's dismissal of the applicant's claims regarding this decision of the Hungarian Tax Authority, the applicant made a review request of its claims to the Curia of Hungary. The Curia examined the case and found that on the one hand, the Hungarian Tax Authority was right and its decision is lawful regarding the notification of a tax difference; because the declaration of a tax difference is not a sanction, but it is a correction of the taxpayer's unlawful behaviour. On the other hand, the Curia of Hungary detailed that the Hungarian Tax Authority imposed the tax penalty and the late payment surcharge as a sanction. Meanwhile regarding the late payment surcharge, the Curia of Hungary specified that it can not be considered as a disadvantage within the meaning of the previously mentioned Decision of Constitutional Court. The late payment surcharge can be identified as a general principle regarding financial delays. The Curia of Hungary also highlighted that the tax penalty is a sanction, thus a disadvantage within the meaning of the previously mentioned Decision of Constitutional Court; because it is not a general principle, but it is based on the decision of the legislator to punish the cases of VAT debt. The Curia of Hungary also agreed with the previously mentioned Decision of the Constitutional Court of Hungary, that it is part of the right to good administration and from this right it can be deduced as a constitutional requirement that no sanction can be imposed after the time-limit established in the law. In view of that, the Curia of Hungary concluded that the imposed tax penalty is unlawful. The Hungarian Tax Authority has only the right to impose tax penalty in the time-limit indicated in the law. It is part of the right to good administration that all administrative authorities - therefore the Hungarian Tax Authority too - respect the time-limits indicated in the law. If an administrative authority does not respect the time limit indicated in the law - as it was in this case -, it can not cause disadvantage for the taxable person.

\subsection{The obligation for cooperation between the administrative bodies and the clients}

Another important aspect of the right to good administration is the obligation for cooperation between the administrative authorities and the clients. One of the most striking examples of a lack of cooperation between the administrative authorities and the clients is the following decision of the Curia of Hungary. ${ }^{22}$ The background of the case can be summarized as follows: the client who fulfilled all

20 See: Decision 7/2013. (III.1.) of the Constitutional Court of Hungary; and Decisions of the Curia of Hungary: Kfv. II.37.078/2012/8., Kfv.II.37.794/2013/4., Kfv.I.35.122/2016/6., Kfv.II.37.574/2015/4., Kfv.III.37.825/2015/8., Kfv. II.37.621/2013/7.

21 See: Decision of the Curia of Hungary: Kfv.I.35.760/2016/6.

22 See: Decision of the Curia of Hungary: Kfv.IV.35.038/2014/5. 
the conditions required by law applied for a state aid. Unfortunately, the client failed to fulfil his obligations regarding a registration required by law. The administrative authority did not alert the client about this obligation in the beginning of the grant period, but made a positive decision regarding the client's grant request and started to allocate the grant, more precisely $90 \%$ of the grant amount. In the following five years, the administrative authority did not ask the client to fill the missing registration and did not inform the client that the failure of this registration will lead to a repayment of the grant. The client used in good faith the grant for its company filling all other requirements. After five years, the client applied for the last $10 \%$ of the grant, and instead of the allocation of the last $10 \%$ of the grant, the administrative authority in its decision reclaimed the $90 \%$ of the grant. The client turned to the court for judicial review of the administrative authority's decision, and the case ended in front of the Curia of Hugary. After the examination of the case, the Curia of Hungary declared that after five years the administrative authority can not reclaim the grant and put the client into this situation regarding a failure which has been already present in the beginning of the grant period and which the administrative authority forgot to mention in the beginning of the grant period. Therefore, in this case the Curia of Hungary expressed that the absence of the cooperation of the public authority directly conflicts with the requirements of the right to good administration.

In another case ${ }^{23}$ regarding the lack of cooperation between the administrative authorities and the clients the following happened: the administrative authority found that in the clients' request there is a deficiency, which may be corrected, therefore the administrative authority asked the client to correct it. The problem was that the administrative authority did not specify the deficiency what the client had to fulfill. We shall note that this deficiency was regarding only one code number, while the whole request of the client except this number was correct. Instead of the correction, the client withdrew his request and made a completely new wrong one. The client later in the court proceedings complained that the administrative authority's request for correction was insufficiently precise. The Curia of Hungary accepted the client's argument that the administrative authority did not clearly state the deficiency. According to this judgement as part of the principle of procedural fairness the obligation for the cooperation between the administrative bodies and the clients should be always taken into consideration by the administrative authority.

Finally, we need to note that both of the above-mentioned cases concerned economic support for young farmers. Therefore, we could expect from the administrative authority a supportive attitude for the realisation of the political objectives. Meanwhile in the mentioned cases we could find the opposite to this expectations. We should also emphasize that the new Act CL. of 2016 on General Public Administration Procedures states in its Basic Principles the obligation for the cooperation between the administrative authorities and the clients. Paragraph 1-2 of Article 2 of this Act expresses that: "(1) The administrative authority (hereinafter referred to as "authority") shall exercise its powers delegated by law within the framework thereof, under the principle of due course of the law. (2) In exercising its powers, the authority shall handle cases: a) professionally and in good faith, having regard to the objectives of simplicity and cooperation with clients; [...]." Regarding the client the obligation for cooperation is declared in Paragraph 1 of Article 6 of this Act, as follows: "All parties to the proceedings are required to act in good faith, and to cooperate with the other parties." We should lastly highlight that the obligation for the cooperation between the administrative authorities and the clients is part of the right to good administration, the non-respect of this obligation may violate the right to good administration.

23 See: Decision of the Curia of Hungary Kfv.IV.35.058/2016/7. 


\section{$5 \quad$ CONCLUSION}

After discussing the constitutional basis of the right to good administration and the right to legal remedy, we examined the relation between the right to legal remedy and the right to good administration. Moreover, we presented several important cases from the last years related to the realisation of the right to good administration: the application of the requirement of a decision within a reasonable time, the duty to justify decisions and the obligation for cooperation between the administrative bodies and the clients.

As a conclusion, we should emphasize that the principle of procedural fairness can be considered the basis of all procedural rights. In its nature it resembles more the principle of human dignity. In its kind it is an absolute right, ${ }^{24}$ but the rights derived from it ${ }^{25}$ - such as the right to legal remedy - are rights which can be restricted in case of the conditions specified by the Fundamental Law of Hungary. The paragraph 3 of Article I. of the Fundamental Law of Hungary defines the general framework of the way of restricting the fundamental rights as follows: "The rules for fundamental rights and obligations shall be determined by special Acts. A fundamental right may be restricted to allow the exercise of another fundamental right or to defend any constitutional value to the extent absolutely necessary, in proportion to the desired goal and in respect of the essential content of such fundamental right." This is the so-called necessity-proportionality test, which was specified in the Constitutional Court's Decision in 1992. ${ }^{26}$ This paragraph of the Fundamental Law of Hungary also introduces the full respect for the objective essential content of such fundamental right.

The principle of procedural fairness as well as the principle of human dignity can be only understood by the examination of its component rights and the effective exercise of these procedural rights is closely linked to the level of the rule of law of a State.

\section{Bibliography:}

BALOGH, Zs. Alkotmánybíróság. In TRÓCSÁNYI, L, SCHANDA, B. (eds.). Bevezetés az alkotmányjogba. Az Alaptörvény és Magyarország alkotmányos intézményei. Budapest : HVG-ORAC, 2016, pp. 406 - 423.

BALOGH-BÉKESI, N. A bírói hatalmi ág az Alaptörvény rendszerében. In IUSTUM AEQUUM SALUTARE, XII., 4 (2016), pp. 9 - 19. Available at <http://ias.jak.ppke.hu/hir/ias/20164sz/02_BaloghBekesi_IAS_2016_4.pdf>. [q. 2018-09-29].

BALOGH-BÉKESI, N. A tisztességes ügyintézéshez és a tisztességes eljáráshoz való jog. In GERENCSÉR, B., BERKES, L., VARGA, Zs. A. (eds.). A hazai és az uniós közigazgatási eljárásjog aktuális kérdései: Current Issues of the National and EU Administrative Procedures (the ReNEUAL Model Rules). Budapest : Pázmány Press, 2015, p. 54.

BOROS, A. Az alapelvek szerepe az uniós és tagállami közigazgatási eljárásjogok rendszerében - A Modell Szabályok értékelése és javaslatok megfogalmazása az uniós alapelvek eljárásjogi szabályozását illetően. In Pro Publico Bono, 2 (2017), pp. 30 - 47.

BOROS, A., PATYI, A. Administrative Appeals and Other Forms of ADR in Hungary. In DRAGOS, D. C., NEAMTU, B. (eds.). Alternative Dispute Resolution in European Administrative Law. Berlin, Heidelberg : Springer-Verlag, 2014, pp. $279-339$.

24 Csink, L. - Marosi, I. Eljárási jogok. In Schanda, B., Balogh, Z. (eds.). Alkotmányjog - Alapjogok. Budapest : Pázmány Press, 2014, p. 271, $273-274$.

25 BALOGH-BÉKESI, N. A tisztességes ügyintézéshez és a tisztességes eljáráshoz való jog. In GERENCSÉR, B., BERKES, L., VARGA, ZS. A. (eds.). A hazai és az uniós közigazgatási eljárásjog aktuális kérdései: Current Issues of the National and EU Administrative Procedures (the ReNEUAL Model Rules). Budapest : Pázmány Press, 2015, p. 54.

26 Decision 30/1992. (V. 26.) of the Constitutional Court of Hungary. 
CSINK, L., MAROSI, I. Eljárási jogok. In SCHANDA, B., BALOGH, Zs. (szerk.). Alkotmányjog - Alapjogok. Budapest : Pázmány Press, 2014, p. 271, 273 - 274.

CHRONOWSKI, N. Mikor megfelelő az ügyintézés? Uniós és magyar alapjogvédelmi megfontolások. In Magyar Jog, 3 (2014), p. 137 - 145.

KÜPPER, H.: Magyarország átalakuló közigazgatási bíráskodása. MTA Law Working Papers 2014/59. Budapest : Magyar Tudományos Akadémia, 2014, pp. 19 - 29.

PATYI, A. and others. Közigazgatási hatósági eljárásjog. Budapest-Pécs : Dialóg Campus Kiadó, 2009.

PATYI, A. The Courts and the Judiciary. In VARGA, A. Zs.,PATYI, A., SCHANDA, B. The Basic (Fundamental) Law of Hungary, A commentary of the New Hungarian Constitution. Dublin : Clarus Press, NUPS, 2015, pp. 204 - 213,

POLLÁK, K. Achievement of the right to legal remedy in the Hungarian Administratives Procedures. In CICKANOVA, D., ILLYOVA, Z., MICATEK, V., RUZICKA, O. (eds.). Collection of Papers from the International Academic Conference Bratislava Legal Forum 2013. Bratislava : Comenius University in Bratislava, Faculty of Law, 2014, pp. $121-131$.

POLLÁK, K. Historical roots of articicle XXVIII, section 7 of the fundamental law of Hungary: On the right to seek legal remedy. In BALOGH, E., SULYOK, M. (eds.). Fundamental rights in Austria and Hungary: Research seminar Vienna, 24 - 25. april 2015. Szeged : Iurisperitus Bt., 2015, pp. 29 - 32.

POLLÁK, K. Quo Vadis: Codification of Administrative Procedure Rules in Hungary and in France. In NEMEC, J. 25 th NISPAcee Annual Conference: Innovation Governance in the Public Sector., Kazan, Oroszország, 2017. 05.18 2017. 05. 20. Bratislava : NISPAcee, 2017, pp. 1 - 8.

SULYOK, T. A tisztességes eljáráshoz való jog újabb kihívásai. In Alkotmánybírósági Szemle, 2 (2015).

TÉGLÁSI, A. Az Alkotmánybíróság. In TÉGLÁSI, A. (ed.). Az állam szervezete. Budapest : NKE 2018, pp. 160 - 180.

VICE ÁDÁNY, T., BALOGH-BÉKESI, N., BALOGH, Zs., HAJAS, B.: Rights and Freedoms. In VARGA, A. Zs., PATYI, A., SCHANDA, B. The Basic (Fundamental) Law of Hungary, A commentary of the New Hungarian Constitution. Dublin : Clarus Press, NUPS, 2015, pp. $79-123$.

Thesis regarding procedural fairness prepared by BALOGH-BEKESI Nora in a co-project of the Constitutional Court of Hungary and the Curia of Hungary (under publication).

Fundamental Law of Hungary

Act I. of 2017 on Administrative Justice

Act CL. of 2016 on General Public Administration Procedures

European Convention on Human Rights

Charter of fundamental rights of the European Union

Decision 49/1998. (XI. 27.) of the Constitutional Court of Hungary

Decision 1/2017. (I. 17.) of the Constitutional Court of Hungary

Decision 39/1997 (VII.1.) of the Constitutional Court of Hungary

Decision 39/1997 (VII.1.) of the Constitutional Court of Hungary

Decision 5/1992. (I. 30.) of the Constitutional Court of Hungary

Decision 9/1992. (I. 30.) of the Constitutional Court of Hungary

Decision 7/2013. (III.1.) of the Constitutional Court of Hungary

Decision 9/2017. (IV. 18.) of the Constitutional Court of Hungary

Decision 30/1992. (V. 26.) of the Constitutional Court of Hungary

Decision Kfv.IV.37.038 / 2016 of the Curia of Hungary

Decision $1 / 2009 \mathrm{KJE}$ of the Curia of Hungary

Decision Kfv.II.37.078/2012/8. of the Curia of Hungary

Decision Kfv.II.37.794/2013/4. of the Curia of Hungary

Decision Kfv.II.37.621/2013/7. of the Curia of Hungary 
Decision Kfv.IV.35.038/2014/5. of the Curia of Hungary

Decision Kfv.II.37.574/2015/4. of the Curia of Hungary

Decision Kfv.III.37.825/2015/8. of the Curia of Hungary

Decision Kfv.I.35.760/2016/6. of the Curia of Hungary

Decision Kfv.I.35.122/2016/6. of the Curia of Hungary

Decision Kfv.IV.35.058/2016/7. of the Curia of Hungary

Official Translations/Summaries of the Decisions of the Constitutional Court of Hungary: http://www.codices.coe.int/ NXT/gateway.dll/CODICES/precis/eng/eur/hun/hun-1997-2-008?fn=document-frameset.htm $\$ \mathrm{f}=$ templates $\$ 3.0$

\section{Contact information:}

Nóra Balogh-Bekesi, Dr.

Balogh-Bekesi.Nora@uni-nke.hu

National University of Public Service, Budapest, Hungary

Ludovika tér 2.

Budapest, 1023

Hungary

Kitti Pollak, Dr.

Pollak.Kitti@uni-nke.hu

National University of Public Service, Budapest, Hungary

Ludovika tér 2.

Budapest, 1023

Hungary 